\title{
21. PETROLEUM-GENERATING POTENTIAL OF SEDIMENTS FROM LEG 41, DEEP SEA DRILLING PROJECT
}

\author{
J.W. Kendrick, A. Hood, and J.R. Castaño, \\ Shell Development Company, Houston, Texas
}

\section{INTRODUCTION}

We acquired several sediment samples from Leg 41 of the Deep Sea Drilling Project for the purpose of investigating the petroleum-generating potential of deep-sea sediments near the continental margin of northwestern Africa. The objectives of this study were to determine whether the sediments contained enough organic matter for significant petroleum generation and whether such sediments had been exposed to sufficiently high subsurface temperatures for the thermal conversion of kerogen to petroleum.

Three methods were used to quantify the organic content of Leg 41 sediments. The total organic carbon content $\left(\mathrm{C}_{\text {ork }}\right)$ was determined by measuring the acidinsoluble carbon in the sediment. For estimates of the effective carbon $\left(\mathrm{C}_{\text {eff }}\right)$ content, i.e., the amount of organic carbon which is thermally convertible to petroleum, two laboratory pyrolysis methods were used. One method, pyrolysis fluorescence (PF), is a rapid means of evaluating the petroleum-generating potential of sediments by measuring (in arbitrary PF units) the amount of fluorescing bitumen generated on heating. The second method, pyrolysis-FID (P-FID), provides a measure of the hydrocarbon-like compounds produced by the laboratory pyrolysis. The effective carbon content is computed as $85 \%$ of the hydrocarbon yield from P-FID.

The thermal history of the sediments was determined by measuring the reflectance of vitrinite, a coal maceral which is disseminated in many sediments. Vitrinite reflectance provides a measure of the level of organic metamorphism (LOM) (Hood et al., 1975), which is applicable over a wide range of coal rank and conditions during which oil and gas are formed.

More complete information about the analytical methods can be found in Hood et al. (in press) and Kendrick et al. (in press).

\section{RESULTS AND DISCUSSION}

Most of the samples for this study came from stratigraphic intervals containing Cretaceous dark colored shales and marls. Our expectations of finding potential, or future, source rocks of petroleum were reasonably high since sediments of similar age and lithology from other DSDP sites in the North Atlantic (Hollister et al., 1972; Hayes et al., 1972) have often been organic rich.

The summary of organic richness measurements in Table 1 indicates that the analyzed sediments contain from $1.11 \%$ to $4.09 \%$ organic carbon. While there are diverse opinions about the organic carbon content a sediment must have to be considered a potential petroleum source rock, Hood et al. (in press) have suggested a minimum value of $1 \%-1.5 \%$ on the basis of published organic carbon values from petroliferous and nonpetroliferous basins. This criterion would indicate that some or all of the Leg 41 samples have the potential of being petroleum source rocks.

The results of the pyrolysis-FID and pyrolysis fluorescence measurements (Table 1) place additional constraints on which samples should be considered potential source rocks. Although several samples contain moderate amounts of organic carbon, in many cases only a small fraction of that organic matter appears to be thermally convertible to petroleum. A notable example is Sample 370-34-4, 146-150 cm, which contains $1.77 \% \mathrm{C}_{\text {org }}$, but only $0.26 \%$ pyrolysis hydrocarbon (HC). Because we do not regard samples with less than $10 \mathrm{PF}$ units or less than $0.3 \%$ hydrocarbons (by P-FID) to be potential source rocks, only the samples from Sites 367 and 369 appear to contain sufficient reactive organic matter to qualify as potential source rocks.

The pyrolysis-FID measurements of Baker et al. (this volume) complement the analyses in this study by further documenting the existence of organic-rich Cretaceous sediments (up to $20 \%$ HC) at Site 367 and, additionally, by demonstrating the occurrence of potential source rocks of similar age at Site 368 .

The results of the vitrinite reflectance measurements (Table 2) indicate that all of the analyzed samples from Leg 41 have LOM's of seven or less, corresponding to coal ranks no higher than subbituminous B. Such low LOM values are typical of sediments which have not been buried more than $1 \mathrm{~km}$ (Hood et al., in press; Kendrick et al., in press), and they indicate that the sediments have not reached the LOM $(\sim 8)$ at which significant oil generation begins (Hood et al., 1975; Vassoyevich et al., 1970).

At Site 368 the Cretaceous black shale sequence is interrupted by a 13.5 -meter-thick diabase sill. Baker et al. (this volume) have shown that the intrusion of the sill had a strong metamorphic effect on the adjacent sediments. This effect, however, dies off rapidly with distance from the sill. Sample 368-63-3, 147-150 cm lies less than 10 meters below the sill and has an LOM of 7, which is not unusually high for sediments buried about $1 \mathrm{~km}$. This observation is in accordance with studies by Bostick (1970) and Correia and Maury (1975), which 
TABLE 1

Organic Richness

\begin{tabular}{lclrrrr}
\hline $\begin{array}{c}\text { Sample } \\
\text { (Interval in cm) }\end{array}$ & $\begin{array}{c}\text { Depth } \\
(\mathrm{m})\end{array}$ & \multicolumn{1}{c}{ Age } & \% C & $\begin{array}{c}\text { PF } \\
\text { (Arbitrary } \\
\text { Units) }\end{array}$ & $\begin{array}{c}\% \text { Hydrocarbon } \\
\text { (HC) from P-FID } \\
\left(300-650^{\circ}\right)\end{array}$ & $\begin{array}{c}\% \mathrm{C}_{\text {eff }} \\
(0.85 \times \% \text { HC) }\end{array}$ \\
\hline $367-19-4,20-25$ & 649 & Turonian & 4.09 & 240 & 2.49 & 2.12 \\
$368-27-2,147-150$ & 388 & Eocene & 1.15 & 1 & 0.18 & 0.15 \\
$368-63-3,147-150$ & 980 & Albian-Turonian & 1.11 & 3 & 0.10 & 0.09 \\
$369 A-43-2,139-142$ & 444 & Albian & 2.30 & 180 & 0.90 & 0.77 \\
$370-22-2,146-150$ & 695 & Albian-Cenomanian & 1.19 & 2 & 0.07 & 0.06 \\
$370-34-4,146-150$ & 879 & Barremian & 1.77 & 2 & 0.26 & 0.22 \\
\hline
\end{tabular}

TABLE 2

Vitrinite Reflectance and Level of Organic Metamorphism

\begin{tabular}{|c|c|c|c|c|c|}
\hline \multirow[b]{2}{*}{$\begin{array}{c}\text { Sample } \\
\text { (Interval in } \mathrm{cm} \text { ) }\end{array}$} & \multicolumn{5}{|c|}{ Vitrinite Reflectance (in oil) } \\
\hline & $\begin{array}{l}\text { Depth } \\
\text { (m) }\end{array}$ & $\begin{array}{c}\text { No. of } \\
\text { Observations }\end{array}$ & Range of $\% R_{o}$ & Mean $\% R_{O}{ }^{\mathrm{a}}$ & $\mathrm{LOM}^{\mathrm{b}}$ \\
\hline $367-19-4,20-25$ & 649 & 18 & $0.16-0.20$ & $0.18 \pm 0.01$ & $<7$ \\
\hline $368-27-2,147-150$ & 388 & 36 & $0.16-0.32$ & $0.22 \pm 0.02$ & $<7$ \\
\hline $368-63-3,147-150$ & 980 & 32 & $0.30-0.61$ & $0.44 \pm 0.03$ & 7 \\
\hline $369 \mathrm{~A}-43-2,139-142$ & 444 & 46 & $0.13-0.31$ & $0.21 \pm 0.01$ & $<7$ \\
\hline $370-22-2,146-150$ & 695 & 18 & $0.16-0.33$ & $0.24 \pm 0.02$ & $<7$ \\
\hline $370-34-4,146-150$ & 879 & 50 & $0.16-0.44$ & $0.26 \pm 0.02$ & $<7$ \\
\hline
\end{tabular}

showed that the thermal effects of dikes were confined to sediments within one or two dike widths of the intrusion. Consequently, the role of small intrusive bodies in metamorphosing potential source rocks appears to be limited. On the other hand, if such sills reflect regionally higher heat flow associated with the volcanic development of the Cape Verde Rise, one might expect oil generation to begin at shallower depths than in regions with normal heat flow. The observation of a "normal" LOM at 980 meters in Site 368 may indicate either that the volcanic activity did not greatly affect the sediments at this site or that such effects are only expressed at greater depths.

During the vitrinite reflectance determinations, visual observations were made of the types of organic matter present in each sample. The relative abundance estimates of the different organic types, summarized in Table 3 , provide a means by which chemical measurements may be related to the nature of the organic matter. Those samples with the highest proportions of effective carbon (Samples 367-19-4, 20-25 cm and $369 \mathrm{~A}-43-2,139-142 \mathrm{~cm}$ ) contain abundant amounts of amorphous organic matter. The remaining samples, by contrast, are relatively richer in vitrinite (or humic) material as well as reworked and thermally inert organic matter. Such samples probably reflect greater proportions of land-derived organic matter, which has lower petroleum-generating potential either because of its chemical composition or because it has been recycled from rocks of higher LOM. The enrichment of amorphous (marine-derived?) organic matter in some sediments may reflect periods of greater marine productivity or conditions more favorable for the preservation of organic matter in the sediments.

\section{SUMMARY}

The results of our analytical work indicate that potential petroleum source rocks do exist in the Cretaceous deep-sea sediments along northwestern Africa. While many sediments contain more than $1 \%$ organic carbon, we believe that only those samples with hydrocarbon yields greater than $0.3 \%$ (by P-FID) should be considered as possible source rocks.

In order for the organic-rich sediments in this area to be considered oil-generating source rocks, they would have to be buried to greater depths than those penetrated by Leg 41 . While Baker et al. (this volume) report intense metamorphism of sediments adjacent to a diabase sill at Site 368 , these effects decrease rapidly away from the sill. The LOM of sediments below the sill do not show evidence of a regional heating event associated with the development of the Cape Verde Rise.

\section{REFERENCES}

Bostick, N.H., 1970. Thermal alteration of clastic organic particles (phytoclasts) as an indicator of contact and burial metamorphism in sedimentary rocks: Ph. D. Dissertation, Stanford Univ., Palo Alto, California, 220 p.

Correia, M.J. and Maury, R.C., 1975. Thermal, mineralogical, and chemical effects of the intrusion of a basaltic dyke in the Toarcian of the Causses: Bull. Centre Rech. Pau-SNPA, v. 9, p. 245-259. 
TABLE 3

Relative Abundance of Types of Organic Matter by Visual Kerogen Analysis ${ }^{a}$

\begin{tabular}{lcccc}
\hline $\begin{array}{c}\text { Sample } \\
\text { (Interval in cm) }\end{array}$ & Amorphous & Liptinitic & Humic & $\begin{array}{c}\text { Reworked } \\
\text { Humic and } \\
\text { Inert }\end{array}$ \\
\hline $367-19-4,20-25$ & 7 & 2 & 2 & 2 \\
$368-27-2,147-150$ & 1 & 1 & 7 & 1 \\
$368-63-3,147-150$ & 1 & 1 & 7 & 4 \\
$369 A-43-2,139-142$ & 7 & 2 & 3 & 3 \\
$370-22-2,146-150$ & 1 & 2 & 7 & 3 \\
$370-34-4,146-150$ & 1 & 2 & 7 & 3 \\
\hline
\end{tabular}

${ }^{\mathrm{a}}$ Numerical abundance scale and percentages (by area): $1=0-1 \%, 2=1 \%$ $5 \% ; 3=5 \%-10 \% ; 4=10 \%-25 \% ; 5=25 \%-50 \% ; 6=50 \%-75 \% ; 7=75 \%$ $100 \%$.

Hayes, D.E., Pimm, A.C., et al., 1972. Initial Reports of the Deep Sea Drilling Project, Volume 14: Washington (U.S. Government Printing Office).

Hollister, C.D., Ewing, J.I., et al., 1972. Initial Reports of the Deep Sea Drilling Project, Volume 11: Washington (U.S. Government Printing Office).
Hood, A. and Castaño, J.R., 1974. Organic metamorphism: Its relationship to petroleum generation and application to studies of authigenic minerals: United Nations ESCAP, CCOP Tech. Bull., v. 8, p. 85-118.

Hood, A., Gutjahr, C.C.M., and Heacock, R.L., 1975. Organic metamorphism and the generation of petroleum: Am. Assoc. Petrol. Geol. Bull., v. 59, p. 986-996.

Hood, A., Castaño, J.R., and Kendrick, J.W., in press. Petroleum-generating potential and thermal history of DSDP Leg 38 sediments. In Talwani, M., Udintsev, G., et al., Initial Reports of the Deep Sea Drilling Project, Volume 38: Washington (U.S. Government Printing Office).

Kendrick, J.W., Hood, A., and Castaño, J.R., in press. Petroleum-generating Potential of Sediments from Leg 40, Deep Sea Drilling Project. In Bolli, H.M., Ryan, W.B.F., et al., Initial Reports of the Deep Sea Drilling Project, Volume 40: Washington (U.S. Government Printing Office).

Vassoyevich, N.B., Korchagina, Yu.I., Lopatin, N.V., and Chernyshev, V.V., 1970. Principal phases of oil formation: Internat. Geol. Rev., v. 12, p. 1276-1296. 